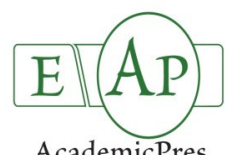

\title{
Over-expression of the Hybrid Aspen Homeobox PttKN1 Gene in Red Leaf Beet Induced Altered Coloration of Leaves
}

\author{
Quan-le $\mathrm{XU}^{1,2}$, Mei-yu RUAN², Ying-jie $\mathrm{TAO}^{1}$, Xin $\mathrm{HU}^{1 *}$

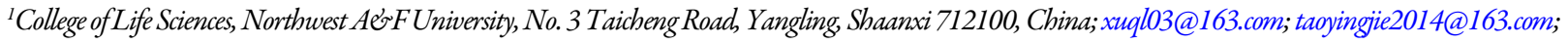 \\ huxin2007@nwsuaf.edu.cn ("correspondingauthor) \\ ${ }^{2}$ Institute of Cell Biology, School of Life Science, Lanzhou University, 222 South Tianshui Road, Lanzhou, Gansu 730000, China; ruanmeiyu@ion.ac.cn
}

\begin{abstract}
PttKNI (Populus tremula $\times$ tremuloides KNOTTEDI) gene belongs to the KNOXI gene family. It plays an important role in plant development, typically in meristem initiation, maintenance and organogenesis, and potentially in plant coloration. To investigate the gene functions further, it was introduced into red leaf beet by the floral dip method mediated via Agrobacterium tumefaciens. The transformants demonstrated typical phenotypes as with other PttKNI transformants. These alterations were very different from the morphology of the wild type. Among them, morphological modification of changed color throughout the entire plant from claret of wild type to yellowish green was the highlight in those transgenic PttKNI-beet plants. The result of spraying selection showed that the PttKNI-beet plants had kanamycin resistance. PCR assay of the 35S-Promoter, NPTII and PttKNI gene, PCR-Southern analysis of the NPTII and PttKNI gene showed that the foreign PttKNI gene had successfully integrated into the genome of beet plant. Furthermore, the results of RT-PCR analysis showed that the gene was ectopic expressed in transgenic plants. These data suggested that there is a correlation between the ectopic expression of PttKNI gene and morphological alterations of beet plants. Pigment content assay showed that betaxanthins concentrations shared little difference between wild type and transgenic lines, while betacyanins content in transgenic plants was sharply decreased, indicating that the altered plant coloration of the transgenic beet plants may be caused by the changed betacyanins content. The tyrosinase study suggested that the sharply decreased of betacyanins content in transgenic plants was caused via the decreased tyrosinase level. Therefore, the reason for the altered plant coloration may be due to partial inhibition of betacyanin biosynthesis that was induced via the pleiotropic roles of PttKNI gene.
\end{abstract}

Keywords: betalains, coloration, floral dip, PttKNI gene, tyrosinase

\section{Introduction}

Flavonoids/anthocyanins, betalains and carotenoids are three main pigments for plant coloration (Tanaka et al., 2008). Among them, carotenoids often have a wide variety in plant tissues, while anthocyanins and betalains do not coexist (Stafford, 1994; Tanaka et al., 2008). In general, anthocyanins are widely distributed in seed plants, but betalains are found in plant species only of the Caryophyllalles order (Stafford, 1994). In the past decades, the biosynthesis and transcriptional regulation of anthocyanins (Koes et al., 2005; Tanaka et al., 2008) and carotenoids (Hirschberg 2001; Howitt Pogson, 2006) are well studied. But the knowledge on betalains is much less than the other two pigments (Tanaka et al., 2008). Betalains are classified into red betacyanins and yellow betaxanthins. They are responsible for brilliant color from yellow to red (Strack et al., 2003) in Caryophyllalles plant including red leaf beet (Beta vulgaris var. cicla $\mathrm{L}$.), which is one of the varieties of leaf beet (Xu et al., 2009). Published data indicated that betalains are derived from tyrosine and then form two pivotal precursors of L-(3, 4-dihydroxyphenyl) -alanine (Dopa) and cyclo-Dopa, which reaction was catalyzed by tyrosinase (Gandia-Herrero et al., 2005; Steiner et al., 1999). These are the first steps in the biogenesis of betalamic acid (then formed betaxanthins) and betacyanins (Gandia-Herrero et al., 2005). Thus, tyrosinase is thought to be the first key enzyme in betalains biosynthetic pathways (Van Gelder $e$ t al., 1997). A clear correlation between the tyrosinase activity and betacyanin content in young Beta vulgaris L. subsp. vulgaris (Garden Beet Group) plants was also reported (Steiner et al., 1999).

PttKN1 (Populus tremula $\times$ tremuloides KNOTTED1), which is a hybrid aspen homeobox gene (Hu et al., 2005; Meng et al., 2009a) plays an important role in plant development, especially in meristem initiation, maintenance and organogenesis (Xu et al.. 2011). It is well reported that the PttKNI transformants of Begonia maculata (Xu et al., 2011), carnation (Meng et al., 2009a), cockscomb (Meng et al., 2009b), Petunia hybrida (Hu et al., 2005) and tobacco (Xu et 
36

al., 2014) produced various morphological alterations compared with their wild type plant. Those phenotypes were mainly focused on altered leaf arrangement (Hu et al., 2005; Meng et al., 2009b; Xu et al., 2011) and leaf morphology like lobed leaf (Hu et al., 2005; Xu et al., 2011; Xu et al., 2014), cup-shaped leaf (Xu et al., 2011) and distorted leaf (Hu et al., 2005; Meng et al., 2009a; Xu et al., 2011; Xu et al., 2014) etc. However, transgenic PttKN1 P. hybrida showed color modification of flower (Hu et al., 2005) and B. maculata showed color modification of leaf (Xu et al., 2011). These phenomena suggested that $P t t K N 1$ gene may regulate the biosynthesis of anthocyanins. In fact, transgenic PttKN1 coleus (Solenostemon scutellarioides) showed a decreased anthocyanins level (Xu et al., 2013).

The present work describes the transformation of red leaf beet using the floral dip method mediated by Agrobacterium tumefaciens. The over-expression of the foreign PttKN1 gene produced pleiotropic morphological alterations including leaf color alteration from claret to yellowish green. This phenomenon suggested that $P t t K N 1$ gene may also impact the biosynthesis of betalain for it is responsible for the coloration of red leaf beet. Further analysis suggested that the alteration was related to the ectopic expression of PttKNI gene and the decreased tyrosinase level.

\section{Materials and methods}

\section{Plant transformation}

Seed balls of red leaf beet (Beta vulgaris L. var. cicla L.) were purchased from Lanzhou Botanical Garden, Gansu Province, China. They were planted and grown in the experimental field of Lanzhou University. The plants were geography separated to protect one sample to fertilize from another. When the plants were grown to inflorescence developmental stage, plant transformation was carried out using floral dip method mediated by $A$. tumefaciens (Clough and Bent, 1998) with minor modifications. A. tumefaciens GV3101 containing pPCV35S : PttKN1 (Meng et al., 2009a) was cultured in YEB medium supplemented with $25 \mathrm{mg} \mathrm{l}^{-1}$ kanamycin $(\mathrm{Km})$ and $75 \mathrm{mg} \mathrm{l}^{-1}$ carbenicillin under the condition of $27^{\circ} \mathrm{C}$ and $180 \mathrm{rpm}$ overnight. After that, 1/2MS medium containing BA $5 \mathrm{mg} \mathrm{l}^{-1}$ and $3 \%$ sugar were prepared as the basic dipping medium. Then the cells were collected by centrifugation $(2,000 \mathrm{~g}, 10 \mathrm{~min})$ and diluted with the above basic medium, or the modified medium that comprised of the basic medium added $0.01 \%$ Silwet L-77 and acetosyringone (AS) either or both into a solution with an optical density at $\mathrm{OD}^{600}$ of approximately 0.3 . Then the plants with developed inflorescence and many immature floral buds were selected to be inoculated with the above prepared $A$. tumefaciens for $1 / 2,1,3,5,10$ and $15 \mathrm{~min}$, respectively. The dipped inflorescences were covered with black plastic for $24 \mathrm{~h}$ to maintain humidity and keep them out of direct sunlight. After 35 wks, seed balls were harvested and vernalized in water solution with $100 \mathrm{mg} \mathrm{l}^{-1} \mathrm{~km}$ at $4{ }^{\circ} \mathrm{C}$ for $48 \mathrm{~h}$. Then the seed balls were sown in mixture of vermiculite, perlite and sphagnum moss

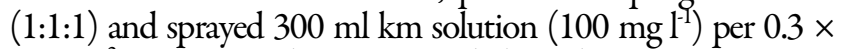
$0.45 \mathrm{~m}^{2}$ twice a week. One month later, kanamycin-resistant seedlings were recorded and the morphologies were observed and photographed. Transformation efficiency expressed as "percentage transformation", was calculated as percentage of kanamycin-resistant seedlings within the total seedlings tested.

\section{PCR assay}

DNA was extracted from the leaves of wild type and putative transgenic plants by improved CTAB method (Doyle, 1990). Transgenic plants were verified via PCR of the PttKN1 gene, NPTII gene and 35S-Promoter. The primers were designed for PttKN1 gene (Forward: 5'-CCATCAAAGCCAAGATCATAG-3' and Reverse: 5'-GGACCATGGCAGATCATATT - 3') to yield 311 bp fragments, NPTII gene (Forward: 5' GTCATCTCACCTT GCTCCTG-3' and Reverse: 5' GGCTTCCATCCGAGTACG$\left.3^{\prime}\right)$ to yield 142 bp fragments and 35S-Pro (Forward: 5AAAGGAAAGGCCATCGTTGAAG-3' and Reverse: 5'ATAGAGGAAGGGTCTTGCGAAG-3’) to yield 192 bp fragments.

PCR was performed in a total volume of $25 \mu$, containing $10 \times$ PCR Buffer ( $\mathrm{Mg}^{2+}$ plus) $2.5 \mu \mathrm{l}, \mathrm{dNTP}(2.5 \mathrm{mM}$ each) $1 \mu \mathrm{l}$, each primer $(10 \mu \mathrm{M}) 1 \mu$, DNA $100 \sim 300 \mathrm{ng}$, TaKaRa Taq $\left(5 \mathrm{U}^{-1}{ }^{-1}\right) 0.2 \mu \mathrm{l}$. PCR conditions were as follows: $94^{\circ} \mathrm{C}$ for $2 \mathrm{~min} ; 32$ cycles of $94^{\circ} \mathrm{C}$ for $15 \mathrm{~s}, 58^{\circ} \mathrm{C}$ (PttKN1, NPT $) / 54^{\circ} \mathrm{C}$ (35S-Pro) for 30 s, and $72^{\circ} \mathrm{C}$ for $1 \mathrm{~min}$; and finally elongated at $72^{\circ} \mathrm{C}$ for $5 \mathrm{~min}$. PCR products were run on $0.8 \%$ agarose gel and photographed with Alpha Imager ${ }^{\mathrm{TM}}$ 2000Documentation Analysis System.

\section{Nest RT-PCR analysis}

Total RNA was isolated from leaves of putative transgenic and wild type plants using the RNA Easyspin Isolation System (Aidlab biotech, Beijing, China). RT-PCR was performed with one step RNA PCR kit (TaKaRa Biotechnology, Dalian, China) according to the manufacturer's instructions. Conditions were the same as the above PCR assay. The PttKN1 gene amplification was carried out using the primers of outer (5'CACCCAATTCCTCGCCTTATG-3' and 5'CTTCCGATGAGCCGACACC-3') and inner (5'CCATCAAAGCCAAGATCATAG-3' and 5'GGACCATGGCAGATCATATT-3’).

\section{PCR-Southern blot}

The PttKN1 and NPTII gene were amplified from pPCV702 plasmid, non-transformed control plant and the putative transgenic plant as the above PCR protocol. Therein, pPCV702 plasmid was regarded as positive control and nontransformed plant as negative control. The primer was the same as the above. PCR products were then separated on a $0.8 \%$ agarose gel and transferred to nylon membranes (Roche) with $20 \times$ standard saline citrate by a standard capillary transfer method (Sambrook and Russell, 2001). The probe preparation, hybridization and detection were performed using the DIGHigh Prime DNA Labeling and Detection Starter Kit I (Roche) according to the manufacturer's instruction.

\section{Betalains content}

Betalains were extracted from the second to fourth true-leaf stage, using about $0.5 \mathrm{~g}$ of wild type and transgenic plants in 25 $\mathrm{ml}$ sodium phosphate-citrate buffer $(\mathrm{pH} \mathrm{5.0)}$ for $30 \mathrm{~min}$ at room temperature. Then the extracts were diluted to $100 \mathrm{ml}$ with the same buffer and centrifuged at 2,500 $\mathrm{g}$ for $10 \mathrm{~min}$. The absorbance at $476 \mathrm{~nm}$ and $535 \mathrm{~nm}$ were measured for betaxanthin and betacyanin, respectively. The pigment concentration was calculated using extinction value $\mathrm{E}(1 \mathrm{~cm} / 1 \%)$ 
of 750 for betaxanthin and 1120 for betacyanin (Nilson, 1970). The results were expressed as $\mathrm{mg} \mathrm{g}^{-1}$ fresh weight. All experiments were performed in triplicate.

\section{Tyrosinase assays}

True leaves from the wild type and transgenic plants, about $0.5 \mathrm{~g}$, were grinded and extracted for $2 \mathrm{~h}$ in $7.5 \mathrm{ml}$ sodium phosphate buffer ( $\mathrm{pH} 7.2)$. After centrifugation (2,000 g, 10 $\mathrm{min}), 6 \mathrm{ml}$ of the extract was diluted to $10.0 \mathrm{ml}$ with the same buffer. The enzyme activity was measured by a modified spectrophotometry as described by Li et al. (2009) with L-dopa (Sigma) as the substrate. The reaction mixture $(5.0 \mathrm{ml}$ of final volume) containing $2.0 \mathrm{ml}$ L-dopa, $0,0.1,0.2,0.3$ or $0.4 \mathrm{ml}$ tyrosinase extract and sodium phosphate buffer $(\mathrm{pH}$ 6.8) to total volume $5.0 \mathrm{ml}$. Then the mixture was incubated at $30^{\circ} \mathrm{C}$ for 10 min and the absorption at $475 \mathrm{~nm}$ due to the formation of dopachrome $\left(\varepsilon_{475}=3700 \mathrm{M}^{-1} \mathrm{~cm}^{-1}\right)$ was measured with a Shimadzu UV-1700 spectrophotometer. All experiments were performed in triplicate.

\section{Statisticalanalysis}

All data were reported as means \pm SE. Statistical analysis was performed using SPSS version17.0 (SPSS Inc., USA). T-test was performed to evaluate the effectiveness of operation. A P $<0.05$ was considered statistically significant.

\section{Results}

\section{Transformation of red leaf beet with floral dip method}

Red leaf beet was transformed via floral dip method and then the seedlings of transformed progeny were selected via kanamycin spraying method. One month later, kanamycinresistant seedlings were recorded and observed. Of the total of 1,600 seed balls sowed for test, 132 exhibited kanamycin resistance. It could be seen that dipped time and medium composition play important roles on the transformation efficiency (Table 1). When $1 / 2 \mathrm{MS}$ added $5 \mathrm{mg} \mathrm{l}^{-1} \mathrm{BA}$ and $3 \%$ sugar was used as the basic $A$. tumefaciens inoculation medium, the red leaf beet plants with many immature floral buds were inoculated $1 / 2,1,3,5,10$ and $15 \mathrm{~min}$, respectively. Therein, instant treatment with $1 / 2 \mathrm{~min}$ could induce putative transformation, and the transformation efficiency was improved along the added dipped time to $5 \mathrm{~min}$ with the highest $2.63 \%$, while further prolonged time was displayed unfavorable. When Silwet L-77 or acetosyringone was added to the basic inoculation medium respectively, they altered transformation efficiency by little compared with the basic medium used. While the two were used in pair, transformation efficiency was upgraded from $1.83 \%$ to $2.57 \%$.

\section{Phenotypes of the transgenic plants}

Normal red leaf beet with two symmetrical cotyledons and claret hypocotyl is a dicotyledonous plant (Fig. 1A). The plants have heart-shaped and claret true leaves (Figs. 1F, 1I), raceme with a columned main inflorescence stem (Fig. 1N). The transformants obtained from the above floral dip method showed different phenotypes compared to their wild type plants. Of the total of 132 kanamycin resistant plants, 67 showed the same color as the wild type with some morphological changes
Table 1. Effects of dipped time and A. tumefaciens inoculation medium on rate of transformation

\begin{tabular}{lc}
\hline Treatment & \% transformation \\
\hline Time $(\mathrm{min})^{*}$ & \\
$1 / 2$ & $0.56 \pm 0.97 \mathrm{a}$ \\
1 & $0.67 \pm 1.15 \mathrm{a}$ \\
3 & $1.83 \pm 1.92 \mathrm{c}$ \\
5 & $2.63 \pm 1.19 \mathrm{~d}$ \\
10 & $1.30 \pm 1.12 \mathrm{~b}$ \\
15 & $1.87 \pm 0.11 \mathrm{c}$ \\
\hline Medium composition ${ }^{* *}$ & \\
\hline Basic medium & $1.83 \pm 1.92 \mathrm{c}$ \\
Basic medium + Silwet L-77 & $1.33 \pm 2.31 \mathrm{~b}$ \\
Basic medium + AS & $1.99 \pm 0.02 \mathrm{c}$ \\
Basic medium + Silwet L-77 + AS & $2.57 \pm 1.07 \mathrm{~d}$ \\
\hline N
\end{tabular}

Note: ${ }^{*}$ basic medium $\left(1 / 2 \mathrm{MS}+5 \mathrm{mg} \mathrm{l}{ }^{-1} \mathrm{BA}+3 \%\right.$ sugar $)$ was used; ${ }^{* *}$ dipped $3 \mathrm{~min}$. The significant difference is 0.05

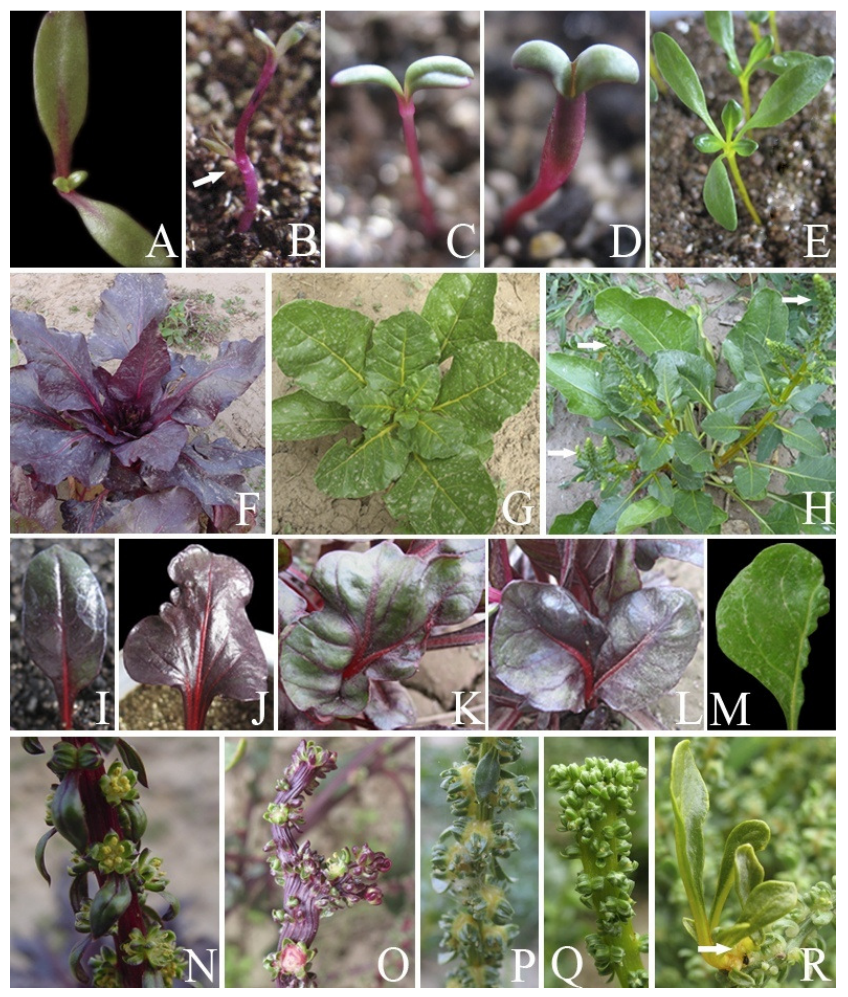

Fig. 1. Phenotypes of the wild type plant of red leaf beet and its transformants. A - wild type plant showed two cotyledons; BE: transgenic beet plant; B - ectopic bud formed from hypocotyl (arrow); C - anisomerous cotyledons; D - cupshaped cotyledon; E - three cotyledons with altered plant coloration; F - wild type plant with heart-shaped and claret true leaves; G-H: transgenic beet plant; G - plant with similar morphology of wild type except for plant coloration; $\mathrm{H}$ - plant with several inflorescence main stems (arrows); I - leaf of wild type; J-M: leaves of transgenic beet plant; J - lobed leaf; $\mathrm{K}$ distorted leaf; L - split leaf with two main veins; $M$ - aberrant leaf with altered color; $\mathrm{N}$ - columned inflorescence stem of wild type plant; O-R: transgenic beet plant; $\mathrm{O}$ - flattened inflorescence stem; P - columned inflorescence stem with altered color; Q - flattened inflorescence stem with altered color; R - ectopic bud formed from inflorescence stem 
38

like ectopic bud formed from hypocotyl (Fig. 1B), anisomerous cotyledon (Fig. 1C), cup-shaped cotyledon (Fig. 1D), lobed leaf (Fig. 1J), distorted leaf (Fig. 1K), split leaf with two main veins (Fig. 1L) and flattened inflorescence stem (Fig. 1O), etc. Among them, lobed leaf and distorted leaf shared the most percent of $0.96 \%$ and $1.62 \%$ respectively, and the other phenotypes appeared sporadically. Simultaneously, the other 65 plants showed altered color from claret to yellowish green throughout the entire plant including cotyledons, hypocotyl, leaves, stem, inflorescence stem and flowers. These transformants showed some novel phenotypes such as plant possesses three cotyledons compared to the wild type's two (Fig. 1E), similar morphology as the wild type except for plant color (Fig. 1G), plants with several columned inflorescence main stems (Fig. 1H), aberrant leaves (Fig. 1M), columned (Fig. 1P) or flattened (Fig. 1Q) inflorescence stem, ectopic bud formed from inflorescence stem (Fig. 1R), etc. Among them, color changed plants with normal morphology as the wild type holds the most of $3.18 \%$.

\section{Identification of transgenic lines}

Of the above morphological alterations, the interest was on those with changed color for they scarcely appeared in the $K N O X I$ included PttKNI gene over-expressed plants. In order to confirm the phenotype alterations were induced by the ectopic expression of the PttKN1 gene, PCR, RT-PCR, and PCR-Southern were conducted. As shown in Fig. 2A, PCR assay of 35S-Promoter, NPTII and PttKN1 gene showed specific bands of $192 \mathrm{bp}, 142 \mathrm{bp}$ and $311 \mathrm{bp}$, respectively, while no signal was detected for the wild type. Further analysis of PCR-Southern of the NPTII and PttKN1 gene was also positive (Figs. 2C, 2D).These results indicated the successfully transformation of red leaf beet via floral dip method and integration of the foreign PttKN1 gene into the genome of red leaf beet. RT-PCR analysis of PttKN1 gene showed a specific band of 311 bp in color changed plants which indicated the ectopic expression of the gene in the transgenic plants.

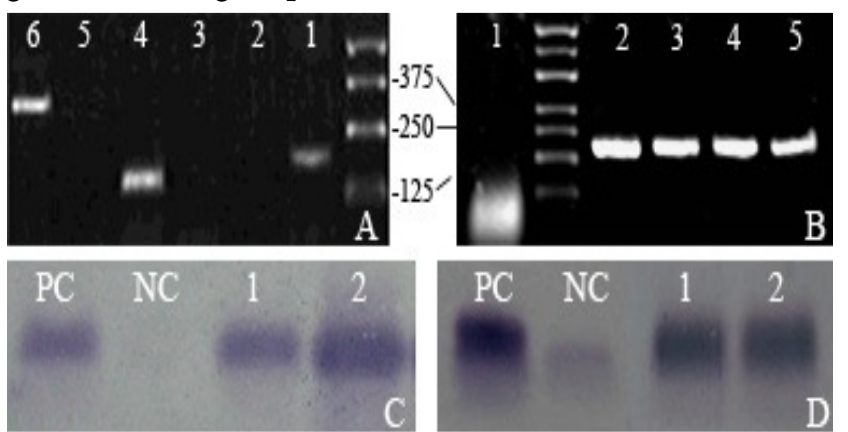

Fig. 2. Molecular assays from the leaves of the putative transgenic plants that had changed color. A: PCR analysis of 35S-Promoter, NPTII and PttKN1 gene; lane 1, 4, 6, putative transgenic plants; lane 2, 3, 5, wild type plant; lane 1-2,35S-Promoter, the $192 \mathrm{bp}$ indicated 35S-Promoter specific band; lane 3-4, NPTII gene, the 142 bp indicated NPTII specific band; lane 5-6, PttKNI gene, the 311 bp indicated PttKNI specific band. B: RT-PCR analysis of PttKNI gene; lane 1, wild type; 25, the color changed plants; the 311 bp indicated $P t t K N 1$-specific bands. C: PCR-southern hybridization of NPTII gene; lane 1-2, the color changed plants. D: PCR-southern hybridization of PttKNI gene; lane $1-2$, the color changed plants. The pPCV702 vector was regarded as positive control and wild type plant as negative control. PC: positive control; $\mathrm{NC}$ negative control

\section{Pigment contents}

The pigments of betacyanins and betaxanthins which have been shown to be a major source of natural colorants in red leaf beet were extracted and measured from the second to fourth true-leaf of wild type and transgenic plants. The results showed that the betacyanins content in transgenic color changed type of $0.15 \pm 0.01 \mathrm{ug} \mathrm{g}^{-1}$ was far below compared with the wild type data of $1.71 \pm 0.14 \mu \mathrm{g} \mathrm{g}^{-1}$. Even so, the betaxanthins content in transgenic color changed type and wild type plant had no significant difference of $1.10 \pm 0.15 \mu \mathrm{gg}^{-1}$ and $1.09 \pm 0.22 \mu \mathrm{gg}^{-1}$, respectively. The results of t-test showed that the differences of betacyanins between wild type and transgenic lines were very significant $(\mathrm{P}<0.05)$, while the differences of betaxanthins between wild type and transgenic lines were not significant $(\mathrm{P}<$ $0.05)$.
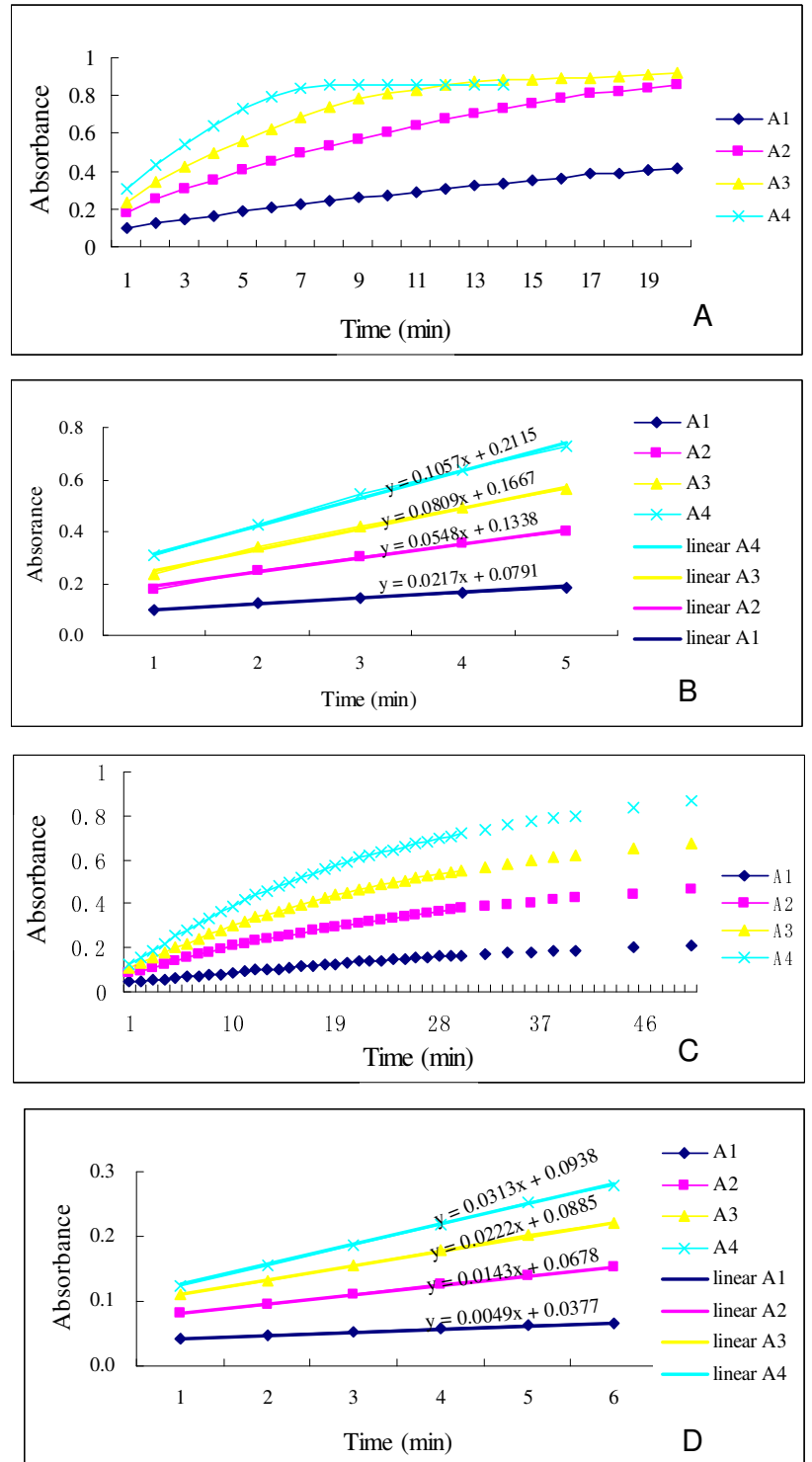

Fig. 3. Conversion kinetic curve was established with the change rate $(\Delta \mathrm{A} / \Delta \mathrm{t})$ of spectro-absorption degree to time, from the wild type and transgenic beet plant that shared similar morphology as the wild type, except for plant color. A conversion kinetic curve and B the initial reaction velocity of the wild type; $C$ conversion kinetic curve and $D$ the initial reaction velocity of transgenic type; $\mathrm{A} 1, \mathrm{~A} 2, \mathrm{~A} 3$ or $\mathrm{A} 4$ represent different volumes of tyrosinase extract used in the reaction mixture, it matches along with $0.1,0.2,0.3$ or $0.4 \mathrm{ml}$, respectively 


\section{Tyrosinase content}

The tyrosinase activity was measured via spectrophotometry with L-dopa as the substrate. The conversion kinetic curve was established with the change rate $(\Delta \mathrm{A} / \Delta \mathrm{t})$ of spectro-absorption degree to time that was taken as the reaction rate, and then the tyrosinase activity was calculated (Fig. 3). The results showed that the tyrosinase content in the wild type and transgenic color changed type plant was $5.96 \pm 0.62\left[\times 10^{-6} \mathrm{~A} /(\mathrm{g} \cdot \varepsilon)\right]$ and $1.63 \pm$ $0.31\left[\times 10^{-6} \mathrm{~A} /(\mathrm{g} \cdot \mathrm{\varepsilon})\right]$, respectively. The tyrosinase level in wild type was about 4 times than it was in transgenic color changed type. The results of $t$-test showed that the difference of tyrosinase level between wild type and transgenic lines was very significant $(\mathrm{P}<0.05)$.

\section{Discussions}

Floral dip method had been used widely for Aabidopsis thaliana transformation (Clough and Bent, 1998; Hay and Tsiantis, 2006) and occasionally for Capsella bursa-pastoris (Bartholmes et al., 2008), Cardamine hirsuta (Hay and Tsiantis, 2006), Medicago truncatula (Curtis, 2004) and Triticum aestivum (Zale et al., 2009) etc. In this report, the method was used to obtain transgenic red leaf beet. The results of kanamycin spraying selection, phenotypes observation and molecular identification indicated that the foreign PttKN1 gene had successfully integrated and expressed into the genome of beet plant. In the past studies, the impact factors of this method on transformation efficiency, like medium composition and additives, had been discussed in detail (Clough and Bent, 1998). Here, the focus was on the roles of dipped time and some additives. It could be seen from Table 1 that the transformation efficiency improved with increased dipped time to $5 \mathrm{~min}$ with the highest $2.63 \%$ and then reduced. These phenomena told us that sufficient inoculation was critical to improve transformation efficiency, while excessive inoculation might be unfavorable. When surfactant Silwet L-77 or chemotactic acetosyringone were added alone, transformation efficiency showed a little difference with the basic medium used. But when the two reagents were used in pair, transformation efficiency was improved. These results suggested that those additives were not necessary for the success of transformation, but important for enhanced transformation; meanwhile, activation of the host plant and $A$. tumefaciens shared the same importance to get higher transformation efficiency.

The successful transformation of the floral dip method on red leaf beet led to several novel phenotypes different from their wild type plants. These phenotypes were mainly focused on the ectopic meristem formation, altered stem morphology and altered leaf morphology such as lobed leaf, distorted leaf etc. These morphological modifications were in highly accordance with other PttKN1 transformants (Hu et al., 2005; Xu et al., 2011). Besides these typical phenotypes, the transgenic PttKN1beet plant displayed changed color throughout the entire plant from claret of wild type to yellowish green. This alteration was rare in those $P t t K N 1$ gene or $K N O X I$ gene transformants.

The plant coloration of red leaf beet was determinate by the chlorophyll, carotenoid and betalain pigments. As there exists only a slight difference of the chloroplast pigment content between the wild type and transgenic color changed plant, it could not be the reason to make the color changed throughout the entire plant (data not show). So, the changed color could only be caused via the betalain pigments alteration. The sharply decreased betacyanins content in transgenic plant confirmed this supposition. Further studies on tyrosinase content indicated that the betacyanins biosynthesis was partly inhibited in transgenic plants. As tyrosinase had two kinds of activities of hydroxylating activity to form Dopa and oxidizing activity to form cyclo-Dopa (Schliemann et al., 1999), and its activity was measured with Ldopa as the substrate, we could infer that the oxidizing activity of tyrosinase was reduced. Consequently, it could concluded that the ectopic expression of $P t t K N 1$ gene in red leaf beet that bring to the changed color from claret to yellowish green might be through regulating the tyrosinase activity. However, the cDNA encoding tyrosinase had not been identified from betalain-producing plants (Tanaka et al., 2008), so how the over-expression of PttKNI gene acts on the process need further investigation. Hatlestad et al. (2012) provided potential clues as they identified a novel cytochrome $\mathrm{P} 450$ that is absolutely required to make betacyanin and without this P450, beets can only make betaxanthin (Hatlestad et al., 2012).

In fact, besides the biosynthesis of betalain pigments could be regulated via the over-expression of $P t t K N 1$ gene in red leaf beet, anthocyanins biosynthesis could also be regulated via the PttKN1 gene in transgenic P. bybrida (Hu et al., 2005), B. maculata (Xu et al., 2011) and coleus (Xu et al., 2013). These suggested an interesting hypothesis that the betalain pathway may have coopted the anthocyanin regulators (Lloyd et al., 2011). Excitingly, analysis of transcriptome data revealed a MYB type transcription factor homologous to the MYBs that could regulate anthocyanin pigments (Lloyd et al., 2011) and activate the biosynthetic genes in the betalain network. Actually, MYB-domain protein was considered the regulator of the KNOX gene expression (Marja et al., 1999). So the expression pattern of MYBs gene induced via the over-expressed $P t t K N 1$ gene may be the further investigation.

\section{Conclusions}

In conclusion, the present work describes the successful application of floral dip method on the genetic transformation of red leaf beet. The expression of the foreign PttKN1 gene produced pleiotropic morphological typically with the same of other PttKN1 transformants and surprisingly the plant coloration changed from claret to yellowish green. This phenomenon was induced via the partly inhibited tyrosinase activity and further a decreased betacyanin level result from it. But how the tyrosinase activity was regulated by over-expressed PttKNI gene remains unclear, as the cDNA encoding the enzyme had not been identified from betalain-producing plants. Moreover, the data of PttKN1 gene on regulating anthocyanins biosynthesis suggested an interesting hypothesis of that the betalain pathway may have co-opted the anthocyanin regulators. However, it remains to be investigated whether the PttKN1 gene roles on the two pathways through the interaction with MYB transcription factor.

\section{Acknowledgements}

This study was supported by the National Natural Science Foundation (31401910) and the Fundamental Research Funds for the Central Universities (2014YB040), P.R. China. 


\section{References}

Bartholmes C, Nutt P, Theissen G (2008). Germline transformation of Shepherd's purse (Capsella bursa-pastoris) by the 'floral dip' method as a tool for evolutionary and developmental biology. Gene 409:1119.

Clough SJ, Bent AF (1998). Floral dip: a simplified method for Agrobacterium-mediated transformation of Arabidopsis thaliana. Plant J 16(6):735-743.

Curtis IS (2004). Production of transgenic crops by the floral-dip method. Methods Mol Biol 286(II): 103-109.

Doyle JJ (1990). Isolation of plant DNA from fresh tissue. Focus 12:1315.

Gandia-Herrero F, Escribano J, Garcia-Carmona F (2005). Betaxanthins as substrates for tyrosinase: An approach to the role of tyrosinase in the biosynthetic pathway of betalains. Plant Physiol 138:421-432.

Hatlestad G, Sunnadeniya R, Akhavan N, Gonzalez A, Goldman I, McGrath J, Lloyd A (2012). The beet R locus encodes a new cytochrome $\mathrm{P} 450$ required for betalain production. Nat Genet 44:816-820.

Hay A, Tsiantis M (2006). The genetic basis for differences in leaf form between Arabidopsis thaliana and its wild relative Cardamine hirsuta. Nature Genetics 38(8):942-947.

Hirschberg J (2001). Carotenoid biosynthesis in flowering plants. Curr Opin Plant Biol 4:210-218.

Howitt CA, Pogson BJ (2006). Carotenoid accumulation and function in seeds and non-green tissues. Plant Cell Environ 29:435-445.

Hu X, Wu QF, Xie YH, Ru H, Xie F, Wang XY, Wang CY (2005). Ectopic expression of the PttKNI gene induces alterations in the morphology of the leaves and flowers in Petunia hybrida Vilm. J Integr Plant Biol 47:1153-1158.

Koes R, Verweij W, Quattrocchio F (2005). Flavonoids: a colorful model for the regulation and evolution of biochemical pathways. Trends Plant Sci 10:236-242.

Li SB, Xue Y, Lv XY, Nie LH, Zhu ML, Zhang HT, Qiu T, Zhou LM (2009). In vitro effect of Ozagrel on mushroom tyrosinase. Protein J 28:182-188.

Lloyd A, Hatlestad G, Gonzalez A, Sunnadeniya R, Akhavan N, Goldman I, McGrath J (2011). Betalains, the other red pigment. Conf Abs P14015. ASPB Plant Biology, Minneapolis, Minnesota, Aug 6-10,2011.

Marja CP, Hudso A, Becraft PW, Nelson T (1999). ROUGH SHEATH2: A Myb Protein That Represses knox Homeobox Genes in Maize Lateral Organ Primordia. Science 284:151-153.
Meng LS, Song JP, Sun SB, Wang CY (2009a). The ectopic expression of PttKN1 gene causes pleiotropic alternation of morphology in transgenic carnation (Dianthus caryophyllus L.). Acta Physiol Plant 31:1155-1164.

Meng LS, Ding WQ, Hu X, Wang CY (2009b). Transformation of PttKN1 gene to cockscomb. Acta Physiol Plant 31:683-691.

Nilson T (1970). Studies into the pigments in beet root (Beta vulgaris L. ssp. vulgaris.var. rubra L.). Lantbrukhogsk Ann 36:179-219.

Sambrook JR, Russell DW (2001). Molecular cloning: a laboratory manual, New York: Cold Spring Harbor.

Schliemann W, Kobayashi N, Strack D (1999). The decisive step in betaxanthin biosynthesis is a spontaneous reaction. Plant Physiol 119:1217-1232.

Stafford HA (1994). Anthocyanins and betalains: Evolution of the mutually exclusive pathways. Plant Science 101(2):91-98.

Steiner U, Schliemann W, Böhm H, Strack D (1999). Tyrosinase involved in betalain biosynthesis of higher plants. Planta 208:114 124.

Strack D, Vogt T, Schliemann W (2003). Recent advances in betalain research. Phytochemistry 62:247-269.

Tanaka Y, Sasaki N, Ohmiya A (2008). Biosynthesis of plant pigments: anthocyanins, betalains and carotenoids. Plant J 54:733-749.

Van Gelder CW, Flurkey WH, Wichers HJ (1997). Sequence and structural features of plant and fungal tyrosinase. Phytochemistry 45:1309-1323.

Xu QL, Xie YH, Ru H, Hu X, Wang CY, Wang XY (2009). Efficient plant regeneration in vitro from red leaf beet via organogenesis. Russ J Plant Physiol 56(4):546-550.

Xu QL, Dong JL, Gao N, Ruan MY, Jia HY, Zhang L, Wang CY (2011). Transgenic lines of Begonia maculata generated by ectopic expression of PttKN1. Biologia 66(2):251-257.

Xu QL, Ruan MY, Hu X (2013). Ectopic expression of the PttKN1 gene in coleus (Solenostemon scutellarioides). Indian J Genet 73(4):419-425.

Xu QL, Gao N, Ruan MY, Ding WQ, Hu X, Wang CY, Wang XY (2015). Ectopic expression of the $P t t K N 1$ gene induced altered leaf morphology and hormonal levels in transgenic tobacco. J Plant Biochem Biotechnol 24(2):197-203.

Zale JM, Agarwal S, Loar S, Steber CM (2009). Evidence for stable transformation of wheat by floral dip in Agrobacterium tumefaciens. Plant Cell Rep 28:903-913. 